\title{
Immunoproteomic analysis of the excretory-secretory products of Trichinella pseudospiralis adult worms and newborn larvae
}

Yang Wang ${ }^{1 \dagger}$, Xue Bai ${ }^{1 \dagger}$, Haichao Zhu ${ }^{1+}$, Xuelin Wang ${ }^{1}$, Haining Shi ${ }^{2}$, Bin Tang ${ }^{1}$, Pascal Boireau ${ }^{1,3}$, Xuepeng Cai ${ }^{4,5}$, Xuenong Luo ${ }^{5}$, Mingyuan Liu ${ }^{1,6^{*}}$ and Xiaolei Liu ${ }^{1 *}$

\begin{abstract}
Background: The nematode Trichinella pseudospiralis is an intracellular parasite of mammalian skeletal muscle cells and exists in a non-encapsulated form. Previous studies demonstrated that T. pseudospiralis could induce a lower host inflammatory response. Excretory-secretory (ES) proteins as the most important products of host-parasite interaction may play the main functional role in alleviating host inflammation. However, the ES products of T. pseudospiralis early stage are still unknown. The identification of the ES products of the early stage facilitates the understanding of the molecular mechanisms of the immunomodulation and may help finding early diagnostic markers.

Results: In this study, we used two-dimensional gel electrophoresis (2-DE)-based western blotting coupled with matrix-assisted laser desorption/ionization time of flight mass spectrometry (MALDI-TOF/TOF-MS/MS) to separate and identify the T. pseudospiralis adult worms ES products immunoreaction-positive proteins. In total, 400 protein spots were separated by 2-DE. Twenty-eight protein spots were successfully identified using the sera from infected pigs and were characterized to correlate with 12 different proteins of T. pseudospiralis, including adult-specific DNase II-10, poly-cysteine and histidine-tailed protein isoform 2, serine protease, serine/threonine-protein kinase ULK3, enolase, putative venom allergen 5, chymotrypsin-like elastase family member 1, uncharacterized protein, peptidase inhibitor 16, death-associated protein 1, deoxyribonuclease II superfamily and golgin-45. Bioinformatic analyses showed that the identified proteins have a wide diversity of molecular functions, especially deoxyribonuclease II (DNase II) activity and serine-type endopeptidase activity.

Conclusions: Early candidate antigens from the ES proteins of T. pseudospiralis have been screened and identified. Our results suggest these proteins may play key roles during the T. pseudospiralis infection and suppress the host immune response. Further, they are the most likely antigen for early diagnosis and the development of a vaccine against the parasite.
\end{abstract}

Keywords: Trichinella pseudospiralis, Excretory-secretory proteins, Immunoproteomics

\footnotetext{
*Correspondence: liumy36@163.com; liuxlei@163.com

${ }^{\dagger}$ Equal contributors

'Key Laboratory of Zoonosis Research, Ministry of Education, Institute of

Zoonosis/College of Veterinary Medicine/College of Basic Medical Science,

Jilin University, Changchun, China

Full list of author information is available at the end of the article
} 


\section{Background}

Trichinellosis is an important food-borne parasitic zoonosis that infects humans and other mammals, with outbreaks in many parts of the world [1, 2]. Humans acquire the disease by consuming raw or undercooked meat of pigs and other animals containing the infective larvae of Trichinella spiralis [3]. Nine different species and three genotypes have been identified to date. Among them, T. nativa, Trichinella T6, Trichinella T9, T. murrelli, Trichinella T8, T. britovi, T. patagoniensis, T. nelsoni and T. spiralis are encapsulated in the host muscle tissues with the formation of collagen layer. Trichinella pseudospiralis, T. papuae and T. zimbabwensis do not induce formation of the collagen layer in the nurse cell [4]. Trichinella spiralis and Trichinella pseudospiralis are independent and typical species in the genus Trichinella. These two species are similar but differ in certain host responses, such as capsule morphology, gene expression, immunological responses and ES products.

After being ingested with infected muscle tissue, the muscle infective larvae (ML) are released and invade the small intestinal epithelium, where larvae complete four moults in 30-40 h and develop into adult worms. The female begins to release the newborn larvae (NBL) over a period of 5-10 days. The NBL penetrate the intestinal wall through the blood and lymphatic circulation into striated muscle, where they grow and form encapsulated and non-encapsulated forms [5]. Trichinella pseudospiralis has a worldwide distribution in Europe, Asia, North America and Australia. It has been detected to infect sylvatic predators such as pigs and rats $[6,7]$, lynx [8] and red foxes [9]. Moreover, this species can infect humans [10] and is the only species that infects birds [11].

Trichinella spiralis and T. pseudospiralis ES products are very similar but are not identical in cDNA sequence, molecular mass, antigenicity and peptide maps of ES products [12-15]. ES products are considered to be directly exposed to the host's immune system, which induces the host immune responses. Consequently, ES products may play a crucial role in the invasion and development of Trichinella larvae $[16,17]$. The ES products of $T$. spiralis include some functional proteins, such as heat shock proteins [18], endonucleases [19], proteinases [20], protein kinases [21, 22], proteinase inhibitors [23], DNA binding [24], and 5'-nucleotidase [25]. The ES products of $T$. pseudospiralis are likely involved in products that have been published, including gp 38, TppSP-1, $45 \mathrm{kDa}$ antigen, TpSerP and $21 \mathrm{kDa}$ ES [17]. The study of the ES products of $T$. pseudospiralis that modulate the host environment to allow parasite development and survival is of fundamental importance to identify the mechanisms leading to immunosuppression and relieving the host inflammatory response in $T$. pseudospiralis-infected host and may provide good markers for diagnosis and candidates for drug and vaccine development.

Recent advances in technology, such as western blotting, indirect immunofluorescence, enzyme-linked immunosorbent assay (ELISA) and proteomics have been utilized to identify the ES proteins of Trichinella spp. $[26,27]$. Proteomics-based analyses involve the simultaneous separation, visualization and quantification of thousands of proteins. More importantly, the combination of proteomics with immunoblotting assays may discover more species-specific antigens than onedimension analysis can. 2-DE and western blotting combined with MALDI-TOF/TOF-MS/MS are an effective approach for the high-resolution analysis and identification of complex groups of ES products.

\section{Methods \\ Parasites and animals}

Trichinella pseudospiralis preserved in Food-Borne Parasitology Laboratory of Key Laboratory for Zoonoses Research, Ministry of Education, Institute of Zoonoses, Jilin University were genotyped and proved by OIE Collaborating Center on Foodborne Parasites in AsianPacific Region in August 2014. Trichinella pseudospiralis (ISS13) ML were isolated by pepsin- $\mathrm{HCl}$ digestion from infected mice at 30 days. Adult worms and NBL were isolated from the infected mice intestines at 6 days postinfection (dpi) [28].

\section{Collection and preparation of $T$. pseudospiralis-infected animal sera}

Trichinella pseudospiralis-infected pig sera were collected from 4 pigs orally infected with 10,000 worms/pig for 26 days. Uninfected sera from the same pigs before infection were collected as negative controls.

\section{Collection of T. pseudospiralis adult worms and NBL proteins sample preparation}

The collected adult worms and NBL were washed several times with sterile PBS and then were cultured in pre-warmed RPMI-1640 supplemented with $100 \mathrm{U}$ penicillin $/ \mathrm{ml}$ and $100 \mu \mathrm{g}$ streptomycin $/ \mathrm{ml}$. The adult worms and NBL were incubated at 5000 worms $/ \mathrm{ml}$ for $20 \mathrm{~h}$ at $37{ }^{\circ} \mathrm{C}$ in $5 \% \mathrm{CO}_{2}$. After incubation, the media containing the ES proteins were centrifuged at $1000 \times \mathrm{rpm}$ at $4{ }^{\circ} \mathrm{C}$ for $5 \mathrm{~min}$ and the supernatant containing the ES products were filtered through a $0.2 \mu \mathrm{m}$ membrane into ultrafiltration device. The ES products were centrifuged at $5000 \times \mathrm{rpm}$ at $4{ }^{\circ} \mathrm{C}$ and were concentrated to $100 \mu \mathrm{l}$. The total protein concentration was determined by Bradford assay [29]. 


\section{Two-dimensional gel electrophoresis}

Three replicates of the ES proteins samples were run in parallel on three immobilized $\mathrm{pH}$ gradient (IPG) strips. Normally, $100 \mu \mathrm{l}$ of ES proteins were diluted to $360 \mu \mathrm{l}$ in rehydration buffer and were loaded into the precast IPG strips (pH 4-7 NL, $17 \mathrm{~cm}$, GE Healthcare, Fairfield, USA). ES proteins were gradient separated by isoelectric focusing (IEF) (GE ETTAN IPGPHOR3). The three IPG strips were rehydrated overnight for $12 \mathrm{~h}$ at $20{ }^{\circ} \mathrm{C}$, followed by IEF under a running parameter (a gradient at $500 \mathrm{~V}$ and $1 \mathrm{~h}$ for $500 \mathrm{Vh}$, a gradient at $1000 \mathrm{~V}$ and $1 \mathrm{~h}$ for $1000 \mathrm{Vh}, \mathrm{a}$ gradient at $8000 \mathrm{~V}$ and $3 \mathrm{~h}$ for $24,000 \mathrm{Vh}$, a step and hold at $8000 \mathrm{~V}$ and $2.4 \mathrm{~h}$ for $19,200 \mathrm{Vh}$, and a step and hold at $500 \mathrm{~V}$ and $0.5 \mathrm{~h}$ for $250 \mathrm{Vh}$ ) to achieve a final level of approximately $45,000 \mathrm{Vh}$ and $8 \mathrm{~h}$ (using a limit of $50 \mu \mathrm{A} /$ strip). After IEF, the IEF strips were first equilibrated in an $8 \mathrm{ml}$ reducing buffer (6 $\mathrm{M}$ urea, $2 \%$ sodium dodecyl sulfate (SDS), $50 \mathrm{mM}$ Tris- $\mathrm{HCl} \mathrm{pH}$ 8.8, 30\% glycerol and $100 \mathrm{mM}$ dithiothreitol) approximately $15 \mathrm{~min}$, followed by an $8 \mathrm{ml}$ alkylation buffer (6 M urea, 2\% SDS, $50 \mathrm{mM}$ Tris- $\mathrm{HCl}, \mathrm{pH} 8.8,30 \%$ glycerol and $250 \mathrm{mM}$ iodoacetamide) for approximately $15 \mathrm{~min}$. Then, the IPG strips were processed by the second-dimensional electrophoresis.

The equilibrated three IPG strips were loaded onto $12 \%$ SDS-PAGE gels by mixing $16 \mathrm{ml}$ of $400 \mathrm{~g} / \mathrm{l}$ acrylamide/ bisacrylamide (29:1 by weight), $10 \mathrm{ml}$ of $1.5 \mathrm{~mol} / \mathrm{l}$ Tris$\mathrm{HCl}(\mathrm{pH} 8.8), 13.48 \mathrm{ml}$ of distilled and deionized water, $100 \mu \mathrm{l}$ of ammonia persulfate (Amersham, Fairfield, USA) and $20 \mu \mathrm{l}$ of tetramethylethylenediamine (TEMED, Amersham). Next, $10 \mathrm{~g} / \mathrm{l}$ low-molecular-weight agarose in SDS electrophoresis buffer was boiled to seal the equilibrated IPG strips to the top of the resolving gel. Gels were run at $2 \mathrm{w} / \mathrm{gel}$ for $60 \mathrm{~min}$ and then at a constant $17 \mathrm{w} / \mathrm{gel}$ until the dye front reached the bottom. The proteins of one gel were stained with Coomassie brilliant blue G-250 (Bio Basic, Amherst, USA) for $6 \mathrm{~h}$. Images of the gels were captured using MICROTEK ScanMakeri800.

\section{Western blotting}

The separated protein spots by 2-DE were transferred to a polyvinylidene fluoride (PVDF) membrane with a wet transfer cell $(400 \mathrm{~mA}, 2.5 \mathrm{~h})$. The PVDF membranes with the ES proteins were blocked with 5\% skim milk in TBST $(80 \mathrm{ml})$ for $1 \mathrm{~h}$ at room temperature. The TBST-blocked PVDF membrane was incubated (overnight, $4{ }^{\circ} \mathrm{C}$ ) with $T$. pseudospiralis-infected swine pooled sera diluted 1:1000 in TBST. After completion of the incubation, the PVDF membrane was washed with the TBST solution $(5 \min \times 3)$, and then the membrane was again incubated with the horseradish peroxidase-conjugated goat anti-mouse IgG (BioRad, Hercules, USA)
(1:8000, $1 \mathrm{~h}$, room temperature). The membrane was washed with TBST solution $(5 \mathrm{~min} \times 3)$ and visualized. Uninfected sera from the same pigs were used as a parallel negative-control. The negative-control experiment used the same method as mentioned above.

The scanned images of the Coomassie brilliant bluestained 2-DE gels combined with the visualized western blot membranes were input to Image Master 2D Platinum 5.0 (GE) to identify species-specific spots.

Proteins identification using MALDI-TOF/TOF-MS/MS analysis The 2-DE gel spots corresponding to the T. pseudospiralis positive serum western blot spot were excised, and the proteins were digested in a gel with trypsin (Promega, Madison, USA). The samples mixed with an equivalent matrix solution ( $\alpha$-cyano-4-hydroxycinnamic acid) were applied for further MALDI-TOF/ TOF-MS/MS analysis using a fuzzy logic feedback control system (Ultraflex III TOF/TOF mass spectrometer, Bruker, Karlsruhe, Germany). MS spectral data were acquired from the samples, and an automatically generated MS/MS list was further analyzed. All mass spectra were recorded in positive reflector mode and generated by accumulating data from 1000 laser shots. The following threshold criteria and settings were used: mass range of $800-4000 \mathrm{Da}$ for detection, UV wavelength of $355 \mathrm{~nm}$, laser frequency of $50 \mathrm{~Hz}$, repetition rate of $200 \mathrm{~Hz}$ and accelerated voltage of 20,000 V. Peptide mass fingerprint (PMF) data were matched to the UniProt Trichinella and NCBInr $T$. pseudospiralis database using profound program under $50 \mathrm{ppm}$ mass tolerance. Data were processed, and proteins were unambiguously identified searching against a comprehensive non-redundant sequence database by using the MASCOT software search engine (http://www.matrixscience.com). With the mascot search results, the protein probability score for the match, molecular weight (MW), isoelectric point (pI), number of peptide matches and percentage of the total sequence covered by the peptides were identified. Protein scores greater than $23(P<0.05)$ were considered significant.

\section{Bioinformatics analysis}

Gene-ontology (GO) analysis was used to further uncover the molecular function and biological process of $T$. pseudospiralis ES proteins with the Quick Go Online Software (http://www.ebi.ac.uk/QuickGO/WebServices.html). Trichinella pseudospiralis ES proteins were divided into different clusters according to molecular function and biological process. 


\section{Statistical analysis}

All mass spectra data were analysed using Mascot software. Mascot adopts a probabilistic scoring algorithm for the identification of proteins, which was adapted from MOWSE algorithm. A $P<0.05$ was considered as statistically significant.

\section{Results}

Trichinella pseudospiralis ES proteins analysis by 2-DE

In an attempt to identify species-specific parasite antigens, adult worms ES proteins were separated by 2-DE in a $17 \mathrm{~cm}, \mathrm{pH} 4-7$ IPG strip (preliminary experiments show that protein points mainly concentrated in the $\mathrm{pH}$ 4-7) and stained with Coomassie brilliant blue G250 (Fig. 1a). More than 400 spots were detected, with pI varying from 4 to 7 and MW from 10 to $170 \mathrm{kDa}$. Spots with a significant decrease (or increase) in their relative abundance were considered differentially expressed proteins if $P<0.05$ and two spots had 1.5 -fold differences in volume.

\section{Immunoblot analysis of ES proteins of adult worms and NBL of $T$. pseudospiralis}

The results of the immunoblot of adult worms ES proteins were shown in Fig. 1b. Approximately 28 immunoreactive protein spots were identified by $T$. pseudospiralis 26 dpi positive serum and matched to the corresponding protein spot in Coomassie brilliant blue stained gels. These matched spots were named spot 1 to 28 and were selected to be further identified through matching of proteins by MALDI-TOF/TOF-MS/MS. These immunoreactive protein spots were observed to have MW ranging from $20 \mathrm{kDa}$ to $130 \mathrm{kDa}$ and $\mathrm{pI}$ values between 4 and 7. Most of these spots had observed MW ranging from $20 \mathrm{kDa}$ to $40 \mathrm{kDa}$ and $\mathrm{pI}$ values between 5 and 6. No proteins reacted to uninfected pig sera (Fig. 1c).

\section{Identification of $T$. pseudospiralis ES proteins by MALDI-TOF/TOF-MS/MS}

Twenty-four of the 28 differentially expressed proteins were successfully identified by PMF, corresponding to 12 species-specific proteins. These proteins are listed in Table 1. Three criteria were used to identify speciesspecific proteins. First, several specific peptides for a given protein were found. Secondly, protein scores greater than $23(P<0.05)$ were considered significant. Finally, the observed MW and pI of the protein measured by 2 -DE were in agreement with the calculated values. Spots 1, 12, 21, 23 and 27 were identified as adultspecific DNase II-10; spots 5, 7, 13, 16 and 26 were

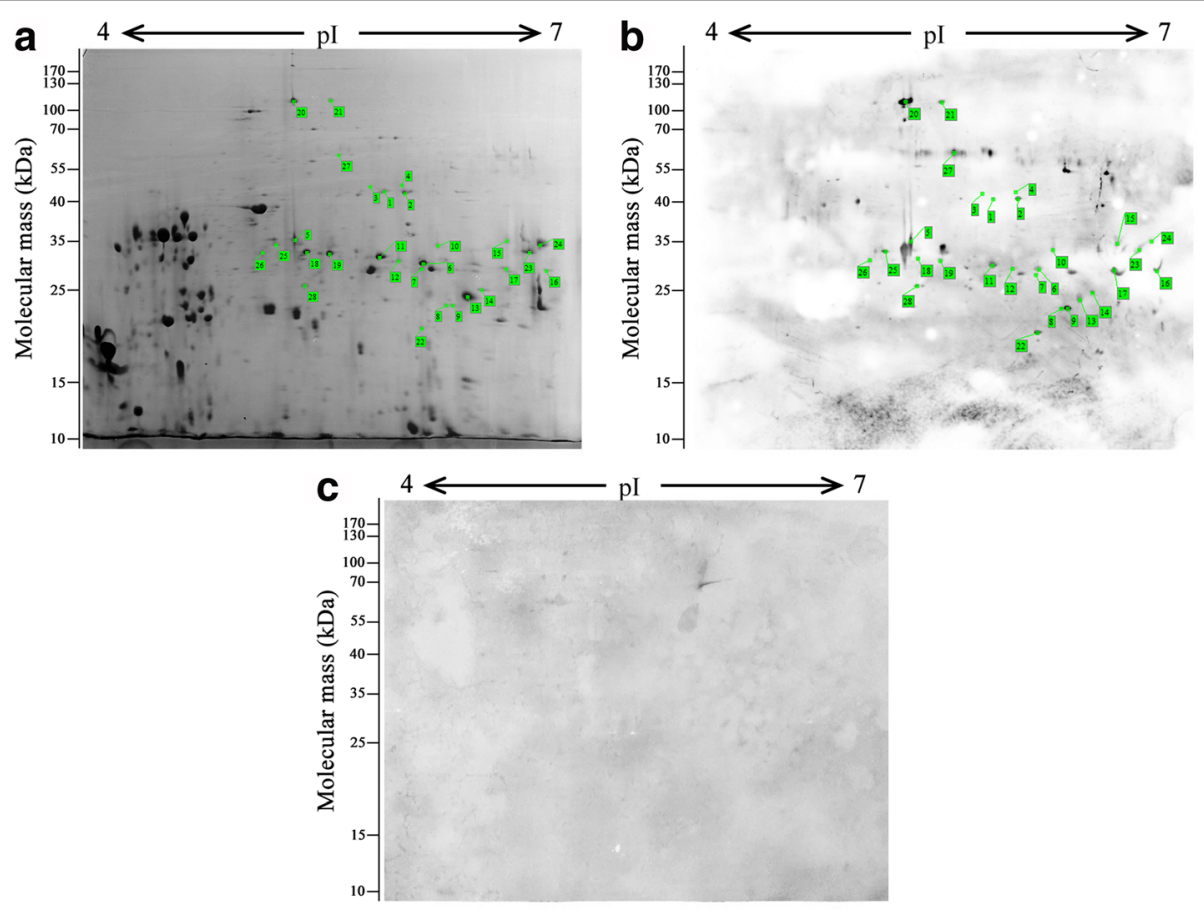

Fig. 1 a Typical two-dimensional electrophoresis (2-DE) gel of Trichinella pseudospiralis adult worms excretory-secretory proteins separated in the first dimension in the $\mathrm{pH}$ range 4-7 and then in the second dimension on a 12\% non-linear gradient polyacrylamide gel. The 2-DE gel was stained with coomassie brilliant blue G-250. Peptide spots selected for analysis are numbered. b Western blot of adult worms excretory-secretory proteins probed with pig infection sera at 26 days post-infection. Peptide spots selected for analysis are numbered. c Western blot of adult worms excretory-secretory probed with normal pig sera 
Table 1 Identification of Trichinella pseudospiralis excretory-secretory proteins by MALDI-TOF/TOF-MS/MS. All the MASCOT scores are $>23(P<0.05)$

\begin{tabular}{|c|c|c|c|c|c|c|c|}
\hline No. & $M S^{a}$ & $M P^{b}$ & $\mathrm{SC}^{\mathrm{c}}$ & $\mathrm{Mw}(\mathrm{KDa}) / \mathrm{pl}^{\mathrm{d}}$ & $\mathrm{Mw}(\mathrm{KDa}) /\left.\mathrm{pl}\right|^{\mathrm{e}}$ & UniProt-NCBInr ID & Description \\
\hline 1 & 71 & 12 & 37 & $38.6 / 6.52$ & $44.9 / 5.83$ & Q32R66_TRISP & Adult-specific DNase II-10 \\
\hline 2 & 216 & 19 & 35 & $50.9 / 6.15$ & $43.9 / 5.95$ & KRX96478.1 & Enolase \\
\hline 3 & 83 & 11 & 13 & $110.6 / 9.40$ & $47.2 / 5.74$ & KRY76695.1 & Serine/threonine-protein kinase ULK3 \\
\hline 4 & - & - & - & - & - & - & Not identified \\
\hline 5 & 110 & 10 & 17 & $49.6 / 6.69$ & $35.5 / 5.30$ & G4XSU5_TRISP & Poly-cysteine and histidine tailed protein isoform 2 \\
\hline 6 & - & - & - & - & - & - & Not identified \\
\hline 7 & 232 & 10 & 15 & $49.6 / 6.69$ & 29.3/6.05 & G4XSU5_TRISP & Poly-cysteine and histidine tailed protein isoform 2 \\
\hline 8 & 37 & 1 & 2 & $50.7 / 9.20$ & $23.1 / 6.19$ & E5SVR8_TRISP & Putative venom allergen 5 \\
\hline 9 & 40 & 1 & 2 & $47.6 / 8.98$ & $23.0 / 6.23$ & KRY01512.1 & Chymotrypsin-like elastase family member 1 \\
\hline 10 & 279 & 9 & 40 & $28.7 / 8.33$ & $34.6 / 6.14$ & E5SZQ3_TRISP & Deoxyribonuclease II superfamily \\
\hline 11 & - & - & - & - & - & - & Not identified \\
\hline 12 & 577 & 15 & 49 & $38.6 / 6.52$ & $31.1 / 5.91$ & Q32R66_TRISP & Adult-specific DNase II-10 \\
\hline 13 & 326 & 12 & 23 & $49.6 / 6.69$ & $24.2 / 6.31$ & G4XSU5_TRISP & Poly-cysteine and histidine tailed protein isoform 2 \\
\hline 14 & - & - & - & - & - & - & Not identified \\
\hline 15 & 152 & 15 & 26 & $72.8 / 8.83$ & $35.4 / 6.54$ & Q9BJM1_TRISP & Serine protease \\
\hline 16 & 266 & 13 & 23 & $49.6 / 6.69$ & $28.9 / 6.77$ & G4XSU5_TRISP & Poly-cysteine and histidine tailed protein isoform 2 \\
\hline 17 & 180 & 12 & 21 & $72.8 / 8.83$ & $29.4 / 6.53$ & Q9BJM1_TRISP & Serine protease \\
\hline 18 & 79 & 11 & 32 & $41.5 / 8.45$ & $33.0 / 5.37$ & KRZ27934.1 & Golgin-45 \\
\hline 19 & 80 & 12 & 10 & $110.6 / 9.40$ & $32.7 / 5.50$ & KRY76695.1 & Serine/threonine-protein kinase ULK3 \\
\hline 20 & 66 & 10 & 42 & $30.9 / 9.20$ & $122.2 / 5.29$ & KRY64535.1 & Uncharacterized protein \\
\hline 21 & 225 & 12 & 35 & $38.6 / 6.52$ & $122.6 / 5.51$ & Q32R66_TRISP & Adult-specific DNase II-10 \\
\hline 22 & 331 & 8 & 16 & $57.1 / 7.56$ & $20.1 / 6.05$ & KRY73124.1 & Peptidase inhibitor 16, partial \\
\hline 23 & 606 & 19 & 61 & $38.6 / 6.52$ & $33.0 / 6.67$ & Q32R66_TRISP & Adult-specific DNase II-10 \\
\hline 24 & 124 & 20 & 30 & $72.8 / 8.83$ & $34.9 / 6.73$ & Q9BJM1_TRISP & Serine protease \\
\hline 25 & 68 & 5 & 82 & $4.97 / 6.55$ & $34.9 / 5.19$ & E5SL33_TRISP & Death-associated protein 1 \\
\hline 26 & 318 & 12 & 21 & $49.6 / 6.69$ & $32.9 / 5.12$ & G4XSU5_TRISP & Poly-cysteine and histidine tailed protein isoform 2 \\
\hline 27 & 175 & 11 & 33 & $38.6 / 6.52$ & $62.7 / 5.55$ & Q32R66_TRISP & Adult-specific DNase II-10 \\
\hline 28 & 82 & 9 & 9 & $110.6 / 9.40$ & $25.9 / 5.36$ & KRY76695.1 & Serine/threonine-protein kinase ULK3 \\
\hline
\end{tabular}

\section{${ }^{a}$ Mascot score}

${ }^{\mathrm{b}}$ Matched peptide

'Sequence coverage (\%)

${ }^{\mathrm{d}}$ Theoretical

Experimental

identified as poly-cysteine and histidine tailed protein isoform 2; spots 15, 17 and 24 were identified as serine protease; spots 3,19 and 28 were identified as serine/ threonine-protein kinase ULK3; other spots were identified as enolase, golgin-45, putative venom allergen 5 , deoxyribonuclease II superfamily, chymotrypsin-like elastase family member 1 , uncharacterized protein, peptidase inhibitor 16 and death-associated protein 1 . Spots 4, 6, 11 and 14 were unmatched to any T. spiralis and $T$. pseudospiralis sequence currently in the database. Fewer peptide matches and a lower percent coverage were tolerated in making a putative assignment of ES proteins identity.

\section{Functional categories of ES proteins from adult worms and NBL of $T$. pseudospiralis by gene ontology}

To further understand the functions of the ES proteins identified by early infection sera in this study, gene ontology annotation was performed. We utilize the UniProt database, and these 12 species-specific proteins were classified into a molecular function and biological process according to GO hierarchy (http://www.uniprot.org//). For the molecular function ontology, the proteins are related to peptidase activity acting on deoxyribonuclease II activity (GO: 0004531, 24\%), serine-type endopeptidase activity (GO: 0004252, 16\%), DNA binding (GO: 0003677, 12\%), nuclease activity (GO: 0004518, 12\%), protein kinase 
activity (GO: 0004672, 12\%), ATP binding (GO:0005524, $12 \%$ ), metal ion binding (GO: 0046872, 4\%), phosphopyruvate hydratase activity (GO: 0004634, 4\%) and magnesium ion binding (GO:0000287, 4\%) (Fig. 2a). A large part of adult worms stage of ES proteins of T. pseudospiralis were related to DNA metabolic process (GO: 0006259, $33.33 \%$ ), proteolysis (GO: 0006508, 22.22\%), protein phosphorylation (GO: 0006468, 16.66\%), nucleic acid binding (GO: 0003676, 5.56\%), zinc ion binding (GO: 0008270, 5.56\%), glycolytic process (GO: 0006096, 5.56\%), Golgi organization (GO: 0007030, 5.56\%) and Golgi to plasma membrane protein transport (GO: 0043001, 5.56\%) (Fig. 2b).

\section{Discussion}

Previous reports have been indicated that the ES products of parasites play important roles in development, adhesion, proteolysis and extracellular matrix organization of the organism [30]. During infection, the ES proteins may control the host immune reaction and recognition, acting as virulence factors or immune regulators [31]. Non-encapsulated species induce less inflammation than do encapsulated species [32], indicating that the ES proteins differ between these organisms. Thus, the study of identifying the ES proteins of adult worms and NBL of T. pseudospiralis are meaningful to reveal intestinal stage host-parasite interactions and understanding the phenomenon of less intestinal inflammation. Also, these ES proteins identified in our study might be candidates for use in developing early diagnostic tests and effective vaccines.

In this study, we successfully employed 2-DE and western blotting combined with MALDI-TOF/TOF-MS/ MS to identify specific ES proteins of adult worms and NBL of $T$. pseudospiralis. Approximately 24 matched protein spots were recognized by PMF and were characterized to correlate with 12 different proteins. To further elucidate the functions of 12 different proteins, we utilized Quick GO online software, and these 12 proteins were categorized based on the GO annotation of biological process and molecular functions. Most of the molecular functions of ES proteins were DNase II activity and serine-type endopeptidase activity. Several proteins had multiple spots with different $\mathrm{pI}$ and MW, such as adult-specific DNase II-10, poly-cysteine and histidine tailed protein isoform 2, serine/threonine-protein kinase ULK3 and serine protease. These proteins might undergo alternative splicing, post-translational modifications, binding to different co-factors or protein processing [17, 33], possibly involving biological regulation, glycolytic process, metabolic process, protein folding and proteolysis.

Previous studies have indicated that the parasitic ES products are composed of many functional proteins involved in host-parasite interactions. In this study, many functional proteins were also identified, especially multiple isoforms of DNase II and serine proteases. DNase II and serine proteases have been proved critical for the
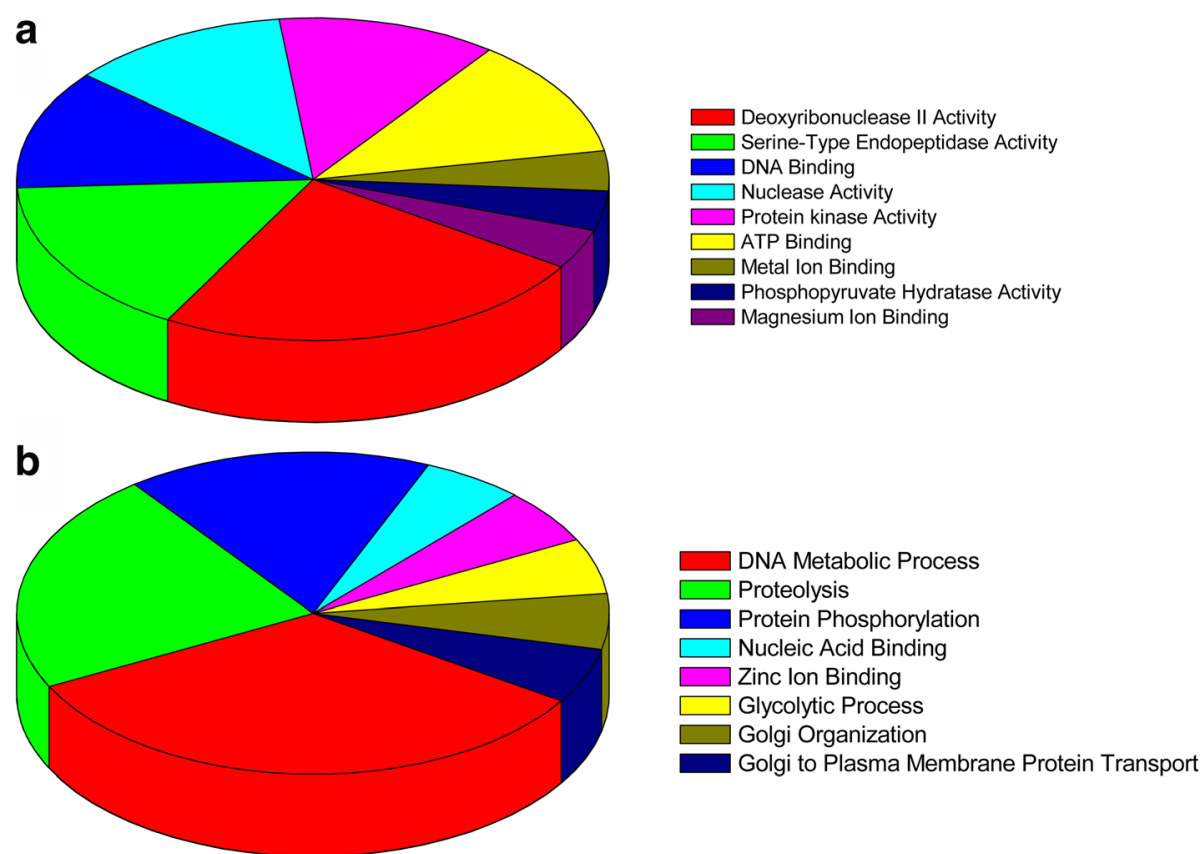

Fig. 2 Gene ontology categories of proteins of adult worms excretory-secretory of Trichinella pseudospiralis. The identified proteins were classified into molecular function (a) and biological process (b) by Quick GO according to their gene oncology signatures 
invasion of the host and modulating host immune responses [34]. DNase II is a well-known acidic endonuclease that fulfils a variety of functions from degrading DNA associated with apoptosis and dietary DNA to modulating host immune responses. Multiple isoforms of the DNase II identified in T. pseudospiralis ES products suggest that DNase II may function as selfprotective molecules by alleviating host intestinal inflammation by cleaving DNA from apoptotic host cells during the larvae invasion of epithelial cells. Furthermore, a novel microbicidal mechanism beyond cell death, recently described as extracellular traps (ETs), was identified in many innate effector cells. ETs are weblike structures composed of chromatin and granular and cytoplasmic proteins, which ensnare and kill microorganisms including bacteria, fungi and parasites [35-37]. However, some of the microorganisms such as Staphylococcus aureus, Streptococcus pneumonia, Vibrio cholera and Leishmania amazonensis have been proved to express endonucleases that efficiently degrade DNA filaments from ETs, allowing these microorganisms to escape the toxic effects of ETs and to invade or spread throughout the host [38-41]. The DNase II secreted from the T. pseudospiralis may have the similar function to escape the fatal attraction of ETs.

Serine proteases reportedly are expressed at different stages and have different functions in establishing the parasitism of $T$. spiralis [42]. Indeed, serine proteinases partially purified from the ES products of $T$. spiralis adult worms exhibit strong biological activity, which plays a vital role in the degradation of intestinal tissues and helps parasites penetrate a diverse range of host tissue barriers, acquire nutrients and evade the host immune response [43]. Meanwhile, serine proteases are also involved in mediating apoptosis-like cell death and phagocytosis [44], which may contribute to parasite-induced immunosuppression. In this study, multiple serine proteases including chymotrypsinlike elastase were identified by sera at $26 \mathrm{dpi}$ of $T$. pseudospiralis, which might be correlative with the invasion of host enterocytes and the suppression of inflammation. However, the functions of serine protease families are strongly context-dependent in parasite infection, and further experimental analyses are necessary to improve the reliability of the functional interpretation of our results.

Compared with the ES products of T. pseudospiralis ML, many stage-specific molecules, such as adult-specific DNase II-10, poly-cysteine and histidine tailed protein isoform2, serine protease, serine/threonine-protein kinase ULK3, enolase, putative venom allergen 5 , chymotrypsinlike elastase family member 1 , uncharacterized protein, peptidase inhibitor 16, death-associated protein 1, deoxyribonuclease II superfamily and golgin- 45 were identified in adult worms. Apart from DNAse II and serine protease families, the poly-cysteine and histidine tailed protein
(PCHTP) were also identified in several spots. The PCHTP as a metalloprotein is a new nematode ES-specific protein family of PCHTP-Poly-cysteine proteins, which are unique to order Trichocephalida [45, 46]. In previous studies, PCHTP sequence analysis showed typical metal binding residues, suggesting that multiple potential metal binding sites may be formed [47, 48]. These metal binding sites consist of cysteine-rich and poly-histidine regions that can bind different bivalent metal ions such as $\mathrm{Fe}, \mathrm{Ni}, \mathrm{Cu}, \mathrm{Co}$ and $\mathrm{Zn}$ and for the first time have been identified in the ES products of non-encapsulated larvae, which most likely play a role in transporting or storing metal ions $[45,46]$. Another three proteins, namely, golgin-45, venom allergen 5 and enolase, were also identified in this study. Golgin- 45 is located on the surface of the medial cisternae of the Golgi complex and maintains the structure of Golgi and secretory protein transport [49]. The venom allergen five gene is identified in many metazoans as the major allergen and is often associated with allergic responses in humans $[50,51]$. The venom allergen five proteins are part of a cocktail of salivary proteins believed to function either in suppressing the host immune system or preventing clotting to prolong feeding [52]. The putative venom allergen five secreted by $T$. pseudospiralis may help adult worms and NBL evade the host immune response. Enolase is a multifunctional protein that catalyzes the reversible dehydration of 2-phospho-D-glycerate (2PGA) to phosphoenolpyruvate (PEP). Parasitic enolase can enhance the activation of plasminogen [53]. Therefore, as a component of ES products, enolase has been confirmed to be a very important virulence factor during invasion into the host [54]. Furthermore, Wang $\mathrm{X}$ et al. recently reported invasion, immune evasion and pathogenesis mechanisms through which Clonorchis sinensis enolase (Csenolase) from ES products participating in plasminogen acquisition and proteolysis may enhance extracellular matrix degradation and control the parasite growth [55]. As a potential vaccine, Csenolase has shown high immunogenicity and has exhibited considerable protective efficacy [56, 57]. In the same way, enolase from $T$. pseudospiralis may contribute to the tissue migration of NBL and host-parasite interactions and may be a vaccine candidate or diagnostic protein.

\section{Conclusions}

In summary, 2-DE and western blotting combined with MALDI-TOF/TOF-MS/MS was used to screen the early candidate antigens from the ES proteins of $T$. pseudospiralis adult worms in this study. Twelve different proteins including adult-specific DNase II-10, polycysteine and histidine tailed protein isoform2, serine protease, serine/threonine-protein kinase ULK3, enolase, putative venom allergen 5 , chymotrypsin-like elastase family member 1 , uncharacterized protein, peptidase inhibitor 16, death-associated protein 1, 
deoxyribonuclease II superfamily and golgin- 45 stagespecific proteins were identified in total. The identification of ES products is critical to understanding the host-parasite interaction and may have broader implications for research on the mechanisms of immunosuppression.

\begin{abstract}
Abbreviations
2-DE: two-dimensional gel electrophoresis; 2PGA: 2-phospho-D-glycerate; Csenolase: Clonorchis sinensis enolase; DNase II: deoxyribonuclease II; dpi: days post-infection; ELISA: enzyme-linked immunosorbent assay; ES: excretory-secretory; GO: gene-ontology; IEF: isoelectric focusing; IPG: immobilized pH gradient; MALDI-TOF/TOF-MS/MS: matrix-assisted laser desorption/ionization time of flight mass spectrometry; ML: muscle larvae; MW: molecular weight; NBL: newborn larvae; PCHTP: poly-cysteine and histidine tailed protein; PEP: phosphoenolpyruvate; pl: isoelectric point; PMF: peptide mass fingerprint; PVDF: polyvinylidene fluoride; SDS: sodium dodecyl sulfate; TEMED: tetramethylethylenediamine
\end{abstract}

\section{Acknowledgements}

Not applicable.

\section{Funding}

This study was supported by the National Key Research and Development Program of China (2017YFD0501302, 2016YFD0500707), National Natural Science Foundation of China (NSFC 31520103916, 31402185, 81201302) and Postdoctoral Science Foundation in China (2015T80310, 2012M520683).

\section{Availability of data and materials}

The datasets generated during the current study have been deposited in the ProteomeXchange Consortium repository under the accession number PXD007783.

\section{Authors' contributions}

MYL and XLL conceived and designed the experiments. YW, XB, HCZ and XLW performed the experiments. HNS, PB and BT contributed the data analysis. YW, XLL and MYL wrote the manuscript. XPC and XNL modify the revised manuscript. All authors read and approved the final manuscript.

\section{Ethics approval}

The study of using laboratory animals was reviewed and approved by the Ethical Committee of Jilin University affiliated to the Provincial Animal Health Committee, Jilin Province, China (Ethical Clearance number IZ-2009-008). All experiments were performed in strict accordance with the requirements of the Animal Ethics Procedures and Guidelines of the People's Republic of China.

\section{Consent for publication}

Not applicable

\section{Competing interests}

The authors declare that they have no competing interests.

\section{Publisher's Note}

Springer Nature remains neutral with regard to jurisdictional claims in published maps and institutional affiliations.

\section{Author details}

'Key Laboratory of Zoonosis Research, Ministry of Education, Institute of Zoonosis/College of Veterinary Medicine/College of Basic Medical Science, Jilin University, Changchun, China. ${ }^{2}$ Mucosal Immunology Laboratory, Pediatric Gastroenterology Unit, Massachusetts General Hospital East, Boston, USA. ${ }^{3}$ ANSES, INRA, ENVA, Universite Paris Est, Laboratory for Animal Health, Maisons Alfort, Paris, France. ${ }^{4}$ China Institute of Veterinary Drugs Control, Beijing 100000, China. ${ }^{5}$ State Key Laboratory of Veterinary Etiological Biology, Key Laboratory of Veterinary Parasitology of Gansu Province, Lanzhou Veterinary Research Institute, CAAS, Lanzhou 730046, China. ${ }^{6}$ Jiangsu Co-innovation Center for Prevention and Control of Important Animal Infectious Diseases and Zoonoses, Yangzhou, China.
}

Received: 1 August 2017 Accepted: 5 November 2017

Published online: 21 November 2017

\section{References}

1. Dupouy-Camet J. Presidential address of ICT12 conference: "Trichinella and trichinellosis - a never ending story". Vet Parasitol. 2009;159(3-4):194-6.

2. Pozio E, Hoberg E, La Rosa G, Zarlenga DS. Molecular taxonomy, phylogeny and biogeography of nematodes belonging to the Trichinella genus. Infect Genet Evol. 2009:9(4):606-16.

3. Dupouy-Camet J. Trichinellosis: still a concern for Europe. Euro Surveill. 2006;11(1):5

4. Pozio E, Zarlenga DS. New pieces of the Trichinella puzzle. Int J Parasitol. 2013;43(12-13):983-97.

5. Li CK, Chung YY, Ko RC. The distribution of excretory/secretory antigens during the muscle phase of Trichinella spiralis and T. pseudospiralis infections. Parasitol Res. 1999;85(12):993-8.

6. Hurnikova Z, Snabel V, Pozio E, Reiterova K, Hrckova G, Halasova D, et al. First record of Trichinella pseudospiralis in the Slovak Republic found in domestic focus. Vet Parasitol. 2005;128(1-2):91-8.

7. Szell Z, Marucci G, Ludovisi A, Gomez-Morales MA, Sreter T, Pozio E. Spatial distribution of Trichinella britovi, T. spiralis and T. pseudospiralis of domestic pigs and wild boars (Sus scrofa) in Hungary. Vet Parasitol. 2012;183(3-4):393-6.

8. Pozio E, Christensson D, Steen M, Marucci G, La Rosa G, Brojer C, et al. Trichinella pseudospiralis foci in Sweden. Vet Parasitol. 2004;125(3-4):335-42.

9. Szell Z, Marucci G, Bajmoczy E, Cseplo A, Pozio E, Sreter T. Spatial distribution of Trichinella britovi, T. pseudospiralis and T. spiralis in red foxes (Vulpes vulpes) in Hungary. Vet Parasitol. 2008;156(3-4):210-5.

10. Andrews JR, Ainsworth $R$, Abernethy D. Trichinella pseudospiralis in man. Lancet. 1993:342(8866):298-9.

11. Pozio E, Shaikenov B, La Rosa G, Obendorf DL. Allozymic and biological characters of Trichinella pseudospiralis isolates from free-ranging animals. J Parasitol. 1992;78(6):1087-90.

12. Kehayov I, Tankov C, Komandarev S, Kyurkchiev S. Antigenic differences between Trichinella spiralis and T. pseudospiralis detected by monoclonal antibodies. Parasitol Res. 1991:77(1):72-6.

13. Kuratli S, Lindh JG, Gottstein B, Smith DF, Connolly B. Trichinella spp.: differential expression of two genes in the muscle larva of encapsulating and nonencapsulating species. Exp Parasitol. 1999;93(3):153-9.

14. Vassilatis DK, Despommier DD, Polvere RI, Gold AM, Van der Ploeg LH. Trichinella pseudospiralis secretes a protein related to the Trichinella spiralis 43-kDa glycoprotein. Mol Biochem Parasit. 1996;78(1-2):25-31.

15. Wu Z, Nagano I, Takahashi Y. Differences and similarities between Trichinella spiralis and T. pseudospiralis in morphology of stichocyte granules, peptide maps of excretory and secretory (E-S) products and messenger RNA of stichosomal glycoproteins. Parasitology. 1998;116(1):61-6.

16. Bolas-Fernandez F, Corral Bezara LD. TSL-1 antigens of Trichinella: an overview of their potential role in parasite invasion, survival and serodiagnosis of trichinellosis. Res Vet Sci. 2006:81(3):297-303.

17. Robinson MW, Greig R, Beattie KA, Lamont DJ, Connolly B. Comparative analysis of the excretory-secretory proteome of the muscle larva of Trichinella pseudospiralis and Trichinella spiralis. Int J Parasitol. 2007;37(2):139-48.

18. Ko RC, Fan L. Heat shock response of Trichinella spiralis and T. pseudospiralis. Parasitology. 1996;112(1):89-95

19. Mak CH, Ko RC. Characterization of endonuclease activity from excretory/ secretory products of a parasitic nematode. Trichinella spiralis Eur J Biochem. 1999:260(2):477-81.

20. Moczon T, Wranicz M. Trichinella spiralis: proteinases in the larvae. Parasitol Res. 1999:85(1):47-58.

21. Arden SR, Smith AM, Booth MJ, Tweedie S, Gounaris K, Selkirk ME. Identification of serine/threonine protein kinases secreted by Trichinella spiralis infective larvae. Mol Biochem Parasit. 1997;90(1):111-9.

22. Gounaris K, Thomas S, Najarro P, Selkirk ME. Secreted variant of nucleoside diphosphate kinase from the intracellular parasitic nematode Trichinella spiralis. Infect Immun. 2001;69(6):3658-62.

23. Nagano I, Wu Z, Nakada T, Matsuo A, Takahashi Y. Molecular cloning and characterization of a serine proteinase inhibitor from Trichinella spiralis. Parasitology. 2001:123(1):77-83.

24. Mak CH, Ko RC. DNA-binding activity in the excretory-secretory products of Trichinella pseudospiralis (Nematoda: Trichinelloidea). Parasitology. 2001; 123(3):301-8. 
25. Gounaris K. Nucleotidase cascades are catalyzed by secreted proteins of the parasitic nematode Trichinella spiralis. Infect Immun. 2002;70(9):4917-24.

26. Cuttell L, Gomez-Morales MA, Cookson B, Adams PJ, Reid SA, Vanderlinde $P B$, et al. Evaluation of ELISA coupled with western blot as a surveillance tool for Trichinella infection in wild boar (Sus scrofa). Vet Parasitol. 2014; 199(3-4):179-90.

27. Nockler K, Reckinger S, Broglia A, Mayer-Scholl A, Bahn P. Evaluation of a western blot and ELISA for the detection of anti-Trichinella-lgG in pig sera. Vet Parasitol. 2009;163(4):341-7

28. Liu MY, Wang XL, Fu BQ, Li CY, Wu XP, Le Rhun D, et al. Identification of stage-specifically expressed genes of Trichinella spiralis by suppression subtractive hybridization. Parasitology. 2007;134(10):1443-55.

29. Bradford MM. A rapid and sensitive method for the quantitation of microgram quantities of protein utilizing the principle of protein-dye binding. Anal Biochem. 1976;72:248-54.

30. Maizels RM, Yazdanbakhsh M. Immune regulation by helminth parasites: cellular and molecular mechanisms. Nat Rev Immunol. 2003;3(9):733-44.

31. Gahoi S, Gautam B. Genome-wide analysis of excretory/secretory proteins in root-knot nematode, Meloidogyne incognita provides potential targets for parasite control. Comput Biol Chem. 2017;67:225-33.

32. Bruschi F, Marucci G, Pozio E, Masetti M. Evaluation of inflammatory responses against muscle larvae of different Trichinella species by an image analysis system. Vet Parasitol. 2009;159(3-4):258-62.

33. Bien J, Nareaho A, Varmanen P, Gozdzik K, Moskwa B, Cabaj W, et al. Comparative analysis of excretory-secretory antigens of Trichinella spiralis and Trichinella britovi muscle larvae by two-dimensional difference ge electrophoresis and immunoblotting. Proteome Sci. 2012;10(1):10.

34. Liu RD, Jiang P, Wen H, Duan JY, Wang LA, Li JF, et al. Screening and characterization of early diagnostic antigens in excretory-secretory proteins from Trichinella spiralis intestinal infective larvae by immunoproteomics. Parasitol Res. 2016;115(2):615-22.

35. Behrendt JH, Ruiz A, Zahner H, Taubert A, Hermosilla C. Neutrophil extracellular trap formation as innate immune reactions against the apicomplexan parasite Eimeria bovis. Vet Immunol Immun. 2010;133(1):1-8.

36. Brinkmann V, Reichard U, Goosmann C, Fauler B, Uhlemann Y, Weiss DS, et al Neutrophil extracellular traps kill bacteria. Science. 2004;303(5663):1532-5.

37. Urban CF, Reichard U, Brinkmann V, Zychlinsky A. Neutrophil extracellular traps capture and kill Candida albicans yeast and hyphal forms. Cell Microbiol. 2006;8(4):668-76.

38. Beiter K, Wartha F, Albiger B, Normark S, Zychlinsky A, Henriques-Normark B. An endonuclease allows Streptococcus pneumoniae to escape from neutrophil extracellular traps. Curr Biol. 2006;16(4):401-7.

39. Berends ET, Horswill AR, Haste NM, Monestier M, Nizet V, von KockritzBlickwede M. Nuclease expression by Staphylococcus aureus facilitates escape from neutrophil extracellular traps. J Innate Immun. 2010;2(6):576-86.

40. Guimaraes-Costa AB, DeSouza-Vieira TS, Paletta-Silva R, Freitas-Mesquita AL, Meyer-Fernandes JR, Saraiva EM. 3'-nucleotidase/nuclease activity allows Leishmania parasites to escape killing by neutrophil extracellular traps. Infect Immun. 2014;82(4):1732-40.

41. Seper A, Hosseinzadeh A, Gorkiewicz G, Lichtenegger S, Roier S, Leitner DR, et al. Vibrio cholerae evades neutrophil extracellular traps by the activity of two extracellular nucleases. PLoS Pathog. 2013;9(9):e1003614.

42. Yang Y, Wen Y, Cai YN, Vallee I, Boireau P, Liu MY, et al. Serine proteases of parasitic helminths. Korean J Parasitol. 2015;53(1):1-11.

43. Todorova VK, Stoyanov DI. Partial characterization of serine proteinases secreted by adult Trichinella spiralis. Parasitol Res. 2000;86(8):684-7.

44. Egger L, Schneider J, Rheme C, Tapernoux M, Hacki J, Borner C. Serine proteases mediate apoptosis-like cell death and phagocytosis under caspase-inhibiting conditions. Cell Death Differ. 2003;10(10):1188-203.

45. Radoslavov G, Jordanova R, Teofanova D, Georgieva K, Hristov P, SalomoneStagni $M$, et al. A novel secretory poly-cysteine and histidine-tailed metalloprotein (Ts-PCHTP) from Trichinella spiralis (Nematoda). PLoS One. 2010;5(10):e13343.

46. Sbirkova HI, Radoslavov GA, Hristov PI, Shivachev BL. Crystallographic conditions of the heterologically expressed recombinant metal-binding protein Ts-PCHTP. Bulg Chem Commun. 2013:45(4):440-5.

47. Gregory DS, Martin AC, Cheetham JC, Rees AR. The prediction and characterization of metal binding sites in proteins. Protein Eng. 1993;6(1):29-35.

48. Yamashita MM, Wesson L, Eisenman G, Eisenberg D. Where metal ions bind in proteins. Proc Natl Acad Sci USA. 1990:87(15):5648-52.
49. Short B, Preisinger C, Korner R, Kopajtich R, Byron O, Barr FA. A GRASP55rab2 effector complex linking Golgi structure to membrane traffic. J Cell Biol. 2001;155(6):877-83.

50. King TP, Spangfort MD. Structure and biology of stinging insect venom allergens. Int Arch Allergy Imm. 2000;123(2):99-106.

51. Muller UR, Johansen N, Petersen AB, Fromberg-Nielsen J, Haeberli G. Hymenoptera venom allergy: analysis of double positivity to honey bee and Vespula venom by estimation of IgE antibodies to species-specific major allergens Api m1 and Ves v5. Allergy. 2009;64(4):543-8.

52. Ribeiro JM, Francischetti IM. Role of arthropod saliva in blood feeding. Sialome and post-sialome perspectives. Annu Rev Entomol. 2003:48:73-88.

53. Nakada T, Nagano I, Wu Z, Takahashi Y. Molecular cloning and functional expression of enolase from Trichinella spiralis. Parasitol Res. 2005;96(6):354-60.

54. Antunez K, Anido M, Arredondo D, Evans JD, Zunino P. Paenibacillus larvae enolase as a virulence factor in honeybee larvae infection. Vet Microbiol. 2011;147(1-2):83-9.

55. Wang X, Chen W, Hu F, Deng C, Zhou C, Lv X, et al. Clonorchis sinensis enolase: identification and biochemical characterization of a glycolytic enzyme from excretory/secretory products. Mol Biochem Parasit. 2011; 177(2):135-42

56. Wang X, Chen W, Tian Y, Mao Q, Lv X, Shang M, et al. Surface display of Clonorchis sinensis enolase on Bacillus subtilis spores potentializes an oral vaccine candidate. Vaccine. 2014;32(12):1338-45

57. Wang X, Hu F, Hu X, Chen W, Huang Y, Yu X. Proteomic identification of potential Clonorchis sinensis excretory/secretory products capable of binding and activating human hepatic stellate cells. Parasitol Res. 2014;113(8):3063-71.

\section{Submit your next manuscript to BioMed Central and we will help you at every step:}

- We accept pre-submission inquiries

- Our selector tool helps you to find the most relevant journal

- We provide round the clock customer support

- Convenient online submission

- Thorough peer review

- Inclusion in PubMed and all major indexing services

- Maximum visibility for your research

Submit your manuscript at www.biomedcentral.com/submit

) Biomed Central 